\title{
Subsidiary Initiative Taking in Multinational Corporations The Relationship Between Power and Issue Selling
}

Dörrenbacher, Christoph; Gammelgaard, Jens

Document Version

Accepted author manuscript

Published in:

Organization Studies

DOI:

$10.1177 / 0170840616634130$

Publication date:

2016

License

Unspecified

Citation for published version (APA):

Dörrenbacher, C., \& Gammelgaard, J. (2016). Subsidiary Initiative Taking in Multinational Corporations: The Relationship Between Power and Issue Selling. Organization Studies, 37(9), 1249-1270.

https://doi.org/10.1177/0170840616634130

Link to publication in CBS Research Portal

\section{General rights}

Copyright and moral rights for the publications made accessible in the public portal are retained by the authors and/or other copyright owners and it is a condition of accessing publications that users recognise and abide by the legal requirements associated with these rights.

Take down policy

If you believe that this document breaches copyright please contact us (research.lib@cbs.dk) providing details, and we will remove access to the work immediately and investigate your claim. 


\section{Subsidiary Initiative Taking in Multinational Corporations: The Relationship between Power and Issue Selling} Christoph Dörrenbacher and Jens Gammelgaard

Journal article (Post print version)

CITE: Subsidiary Initiative Taking in Multinational Corporations: The Relationship Between Power and Issue Selling. / Dörrenbacher, Christoph; Gammelgaard, Jens. In: Organization Studies, Vol.

37, №. 9, 09.2016, p. 1249-1270.

DOl: 10.1177/0170840616634130

Uploaded to Research@CBS: June २०१७ 


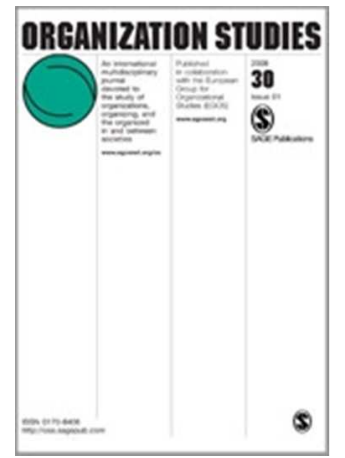

\section{Subsidiary Initiative-taking in Multinational Corporations: The Relationship between Power and Issue-selling}

\begin{tabular}{|c|l|}
\hline Journal: & Organization Studies \\
\hline Manuscript ID & OS-13-0614.R3 \\
\hline Manuscript Type: & $\begin{array}{l}\text { SI: New organizational perspectives on the study of politics and power in } \\
\text { the multinational company (Deadline for submissions: 20th December } \\
2013\end{array}$ \\
\hline Keywords: & $\begin{array}{l}\text { Qualitative comparative analysis (QCA, fs/QCA) < Data Analysis, } \\
\text { Interviews < Research Design and Data Collection, Communicative } \\
\text { constitution of organizations (CCO) < Theoretical Perspectives, Resource } \\
\text { dependence theory < Theoretical Perspectives, Corporations, } \\
\text { multinationals < Topics, Power, domination, resistance < Topics }\end{array}$ \\
\hline Abstract: & $\begin{array}{l}\text { This paper investigates the political maneuvering that accompanies } \\
\text { subsidiary initiative taking in multinational corporations (MNCs). On the } \\
\text { basis of an explorative empirical investigation of subsidiary initiative taking } \\
\text { in the French subsidiaries of six German MNCs, the paper explores the } \\
\text { activities that subsidiaries undertake to sell their initiatives, and the } \\
\text { relationships among issue selling, subsidiary power and headquarters' } \\
\text { hierarchical power. The findings suggest that the use of issue-selling tactics } \\
\text { is common when subsidiaries engage in initiative taking. In addition, the } \\
\text { paper demonstrates that a low degree of issue selling is needed to obtain } \\
\text { approval of an initiative in less asymmetrical headquarter-subsidiary power } \\
\text { relationships (i.e. relationships in which subsidiaries are relatively } \\
\text { powerful). In cases where power relationships are highly asymmetrical, } \\
\text { issue selling is a necessity, but it is hardly a sufficient condition for } \\
\text { obtaining headquarters' approval. This renders issue selling to a second- } \\
\text { rank power in subsidiary initiative taking, as it only works in conjunction } \\
\text { with subsidiary power. }\end{array}$ \\
\hline
\end{tabular}




\section{Subsidiary Initiative Taking in Multinational Corporations: The Relationship between Power and Issue Selling}

\section{Introduction}

Subsidiary initiative taking occurs when subsidiaries of multinational corporations (MNCs) engage in entrepreneurial activities independent of their headquarters' will. This common occurrence serves as a bottom-up complement to the many headquarters-inspired transfer processes, and it accounts for many of the dynamics that characterize contemporary MNCs. At the same time, subsidiary initiative taking is one of the main ways in which local elements find their way into the emerging global strategies of MNCs.

Mudambi et al. (2014) suggest that the success of a subsidiary initiative depends on the power a subsidiary holds. Ambos et al. (2010) claim that subsidiary initiatives need to attract headquarters' attention in order to be successful. In this regard, Ambos et al. (2010) refer to a broader concept of politicking in organizations that has been labeled 'issue selling' (Dutton and Ashford, 1993). However, the actual use of power and politics in the process of initiative taking has remained unexamined in the extant literature. Therefore, this paper analyzes issueselling tactics used in subsidiary initiative taking. Furthermore, it explores the relationships between issue selling and a subsidiary's power base in subsidiaries' interactions with headquarters, which by definition possesses hierarchal and, therefore, dominant power.

The paper proceed as follows. First, we define subsidiary initiatives and examine issue-selling strategies. We then take a look at subsidiary power characteristics, discuss the MNC's asymmetrical power distribution, and develop a 'skeletal conceptual framework' (Denis et al., 2000, cited in Welch et al., 2011: 751) that distinguishes among three types of power: subsidiary power, subsidiary issue-selling power and headquarters hierarchical power. Next, we present empirical findings from six case studies of French subsidiaries of German MNCs. Based on these findings, we present an in-depth theoretical discussion of the concept of issue selling in subsidiary initiative taking and develop a model that links issue selling in subsidiary initiative taking to concepts of organizational power. The paper closes with our conclusions and some remarks on the implications of our empirical findings.

\section{Subsidiary initiative taking: Definition, types and driving factors}

Subsidiary initiatives are defined as 'entrepreneurial activities carried out by foreign subsidiaries of multinational corporations' (Birkinshaw and Ridderstråle, 1999: 14). In order to advance the way in which the MNC uses or expands its resources, such initiatives must not only be discrete and recognizable but also proactive and influential (Ambos and Birkinshaw, 2010). Delany (2000) characterizes such initiatives as 'domain developing' because the subsidiary goes beyond its current mandates. The most effective initiatives are those in which the subsidiary is able to change the rules of competition in its industry through its actions (Bouquet and Birkinshaw, 2008). Therefore, the concept of subsidiary initiatives does not include minor adaptations to the market or incremental product developments. Rather, it refers to a subsidiary's adoption of new technologies, its entrance into new markets or the enlargement of its product portfolio. 
Subsidiary initiatives typically start with efforts within the subsidiary to identify opportunities. Those opportunities are developed and formalized into initiatives, and negotiations are launched with headquarters regarding the commitment of resources to those opportunities. Three profound factors explain the enduring existence of subsidiary initiatives in MNCs (Dörrenbächer and Gammelgaard, 2011). First, subsidiaries regularly come across lucrative business opportunities in their environments. Second, subsidiaries have a significant interest in enhancing their position in the MNC and in safeguarding their long-term survival via initiatives. Third, some subsidiary managers do not view their role as restricted to implementing headquarters' orders; their entrepreneurial personalities lead them to engage in initiative taking.

\section{Politicking and issue selling in subsidiary initiatives}

As indicated above, subsidiaries have specific interests in launching initiatives, but they need to involve headquarters either for approval of their initiatives or for additional resources to support their initiatives. As a consequence, headquarters may be inundated with subsidiary initiative proposals and it must filter out those that appear to be the most promising. Headquarters' primary interest is to assess the overall performance effect of each proposed initiative for the MNC as a whole - not for the subsidiary itself. Consequently, headquarters must carefully examine the subsidiaries' initiative-taking processes, as such initiatives have been found to create managerial rent-seeking problems (Mudambi and Navarra, 2004). However, headquarters' management may also engage in irrational behavior (Birkinshaw and Ridderstråle, 1999). In such situations, headquarters - spurred by resistance to change, ethnocentrism and fear of the unknown - tend to apply a very fine-meshed corporate immune system that sometimes filters out valuable subsidiary initiatives.

Ambos et al. (2010) provide evidence that headquarters intensely monitor subsidiaries that take initiatives. Therefore, subsidiary initiative taking requires subsidiaries to engage in careful political maneuvering. In this regard, subsidiary actors use political language and engage in various tactics to remove opposition or to gain influence. As outlined by Yukl and Tracey (1992), common tactics include the use of pressure, persuasion and appeals; the legitimization of the issue by addressing reputation problems; the undertaking of exchanges with headquarters; and the establishment of strong coalitions with partners (such as other subsidiaries).

More recently, political maneuvering in organizations has been referred to as 'issue selling' (Dutton and Ashford, 1993; Ling et al., 2005). Dutton and Ashford (1993: 398) define issue selling as an 'individual's behaviors that are directed towards affecting others' attention to and understanding of issues'. These authors outline a number of tactics that middle managers use to convince top management of the value of their initiatives and, thereby, influence top management's decision making. Therefore, while Dutton and Ashford's (1993) framework serves as a generic model of firm negotiations, it does not emphasize issue selling in headquarters-subsidiary relationships. In fact, this relationship has thus far been dealt with in a rather piecemeal manner. For example, Crane (2000) considers issue selling and ethical issues in relation to corporate greening. Ling et al. (2005) investigate how issue-selling tactics and effectiveness vary with the cultural context. Gammelgaard (2009) demonstrates that expatriate subsidiary managers are much more effectual in issue selling than local managers of subsidiaries. Finally, Erkama and Vaara (2010) examine how subsidiaries use rhetoric when attempting to resist headquarters' decisions, especially when those decisions imply 
plant closures. The study also demonstrates how effective issue selling can be - in the focal case, the subsidiary managed to delay a plant closure by several years.

Much of the literature related to issue-selling tactics focuses on how middle (subsidiary) managers frame an issue, the path of knowledge flows or the need for proper preparation based on relevant data (Bishop et al., 2011; Gammelgaard, 2009). For example, Dutton et al. (2001) deal with the contextual characteristics of the knowledge used in issue selling. Basically, issue selling adds value by addressing the asymmetrical distribution of information between headquarters and the subsidiary. From headquarters' point of view, informational asymmetries arise from the hidden characteristics, intentions, knowledge and actions of the subsidiary (Saam, 2007). Through issue selling, subsidiaries reveal and explain facts related to the local environment to decision makers at headquarters (Gammelgaard, 2009). In their issue-selling strategies, subsidiaries can contextualize knowledge, although Sperber and Wilson (1995: 16) argue that the clarified context does not necessarily build on 'pure facts' but can be influenced by 'expectations about the future, scientific hypotheses or religious beliefs, anecdotal memories, general cultural assumptions, [or] beliefs about the mental stage of the speaker'. Issue selling should, therefore, be viewed as broader than 'knowledge transfers' - it is used to make headquarters 'familiar' with the subsidiary's situation. In that regard, it stresses the need for initiative approval (Schulz, 2003) and is used to persuade headquarters (Yang et al., 2008). This implies that subsidiaries are motivated to transfer knowledge because that knowledge holds the potential to strengthen their strategic positions in the MNC (Mudambi and Navarra, 2004). However, informational asymmetries also reflect an agency problem (Mudambi, 2011; Seem, 2007) - subsidiaries may act opportunistically and use their power for individual rent seeking.

While studies on issue selling include the MNC context, they do not emphasize subsidiary initiatives. In this paper, therefore, we focus on issue selling in subsidiary initiative taking. Two factors seem important in this regard. First, subsidiaries must attract headquarters' attention. As initiatives are often autonomously generated, subsidiaries need to make headquarters aware of the relevance of each initiative and its value. Second, when initiatives are related to domain developments, we assume, in line with Mattes and Späth (2013), that subsidiaries will utilize more informal channels of politicking, which are often labeled 'lobbying'.

In terms of attracting headquarters' attention, MNCs are often large and complex entities in which headquarters typically face constraints in approaching and relating to all subsidiaries (Nohria and Ghoshal, 1997). However, as shown by Birkinshaw et al. (2006), a subsidiary can attract headquarters' attention by highlighting distinguishing external elements, such as its location in an important market. Another means of attracting headquarters' attention is image control in which the subsidiary actively manages its image of being credible, reputable and a high performer. Dutton and Ashford (1993) suggest that linking an issue to a legitimacy problem is another effective way to attract attention. Furthermore, a good track record with previous initiatives might garner headquarters' attention for a new initiative. Finally, Dutton and Ashford (1993) suggest that framing an issue to fit headquarters' preferences is an effective way of attracting attention. For example, an initiative to obtain a new mandate can be framed as a human-resource issue, a cost issue, a technical issue or some other issue (Cowan, 1991) that corresponds to one of headquarters' focal interests.

Subsidiaries lobby for an initiative when they 'exercise a voice' (Cantwell and Mudambi, 2005: 1109) in order to promote a particular initiative. Lobbying to promote an initiative 
involves 'personal appeals, behind the scenes negotiations, or discussions in halls' (Dutton and Ashford, 1993: 419) with any actor who might have an impact on the initiative.

The subsidiary's ability to attract attention or to lobby is moderated by adoption of certain tactics, but the subsidiary's power is assumed to have a strong influence on its success in issue selling (Birkinshaw and Ridderstråle, 1999). In the original issue-selling model developed by Dutton and Ashford (1993), power is conceptually included as 'perceived power'. In other words, managers' willingness to promote a specific issue is influenced by their perceptions of their power positions. However, we suggest that both subsidiary power characteristics and the MNC's asymmetrical power distribution must be considered when studying subsidiary initiative taking. These two subjects are therefore addressed in the following subsections.

\section{Subsidiary power characteristics}

MNCs are organized as hierarchies in which power is asymmetrically distributed between headquarters and subsidiaries. Most power studies investigate how actor A is dominant relative to actor B. Studies focused on actor B's power generally investigate how actor B can resist the constraints imposed by actor A (Lukes, 2005; Wartenberg, 1990). However, if we turn the equation around, we can investigate how actor B may be able to constrain dominant actor A's decision making. This allows us to examine the power bases that subsidiaries can utilize to get their initiatives approved rather than analyzing how subsidiaries resist headquarters' strategies (Bouquet and Birkinshaw, 2008). Resistance is associated with power, as 'power' can be defined as the ability to achieve one's will even when faced with resistance from others (Lukes, 2005). Therefore, resistance is not a direct expression of power, but rather an obstacle actors face when attempting to realize their will. Consequently, in the power literature, resistance is associated with low-power actors, as they can only resist a situation rather than change it.

The international business literature has investigated a range of situations in which certain subsidiary characteristics provide the subsidiary with power. A subsidiary obtains power when it possesses certain resources, network positions, value-chain mandates or other means needed to capitalize on institutional and market conditions (Ferner et al. 2004). Bouquet and Birkinshaw (2008) find that actors without critical resources are typically unable to exert much influence. In order to be powerful, therefore, the subsidiary must possess resources upon which the headquarters or the $\mathrm{MNC}$ as a whole are dependent (Bouquet and Birkinshaw, 2008). In addition, Pfeffer and Salancic (1978) assert that those resources must be scarce and that there must be a high degree of competition among subsidiaries to possess them. However, Astley and Sachdeva (1984) and Forsgren et al. (2005) claim that the subsidiary does not necessarily need to possess the resources - it only needs to control the relationships that provide access to them. Such control might, for example, be derived from specific relationships with decision makers in public-tender offers (Dörrenbächer and Gammelgaard, 2010), or access to information about certain organizations, persons, norms or procedures (Mechanic, 1962).

Subsidiaries typically operate in selected parts of the value chain. Given their specialization, some subsidiaries provide services to other parts of the MNC (Birkinshaw and Morrison, 1995). Therefore, subsidiaries can hold some power in situations where headquarters faces sunk costs when it wishes to restructure the value chain (Astley and Zajac, 1991; Dörrenbächer and Gammelgaard, 2011). Mudambi et al. (2014) find that this type of functional power affects strategic decision making in the MNC. 
Subsidiaries also gain power through their ability to help the MNC deal with critical legitimacy issues. In fact, even peripheral subsidiaries can become powerful if they can prevent legitimacy crises (Hart and Sharma, 2004). Local host-country institutions, such as strong labor unions, can also be supportive for the subsidiary and the subsidiary may use them to pressure headquarters (Bouquet and Birkinshaw, 2008; Clark and Geppert, 2011; Williams and Geppert 2011). However, in such cases, headquarters has an opportunity to undercut the union pressure by threatening the subsidiary with closure (Mir and Sharpe, 2009).

Harzing and Sorge (2003) suggest that headquarters has distinct preferences for the types of host countries in which it wishes to invest, which puts subsidiaries in some countries in an advantageous position. The same argument can be made for those markets with high economic potential - markets in which market size or growth alone can serve as an argument for the acceptance of a subsidiary initiative (Gammelgaard, 2009).

Overall, we conclude that the subsidiary characteristics discussed above are likely to lead to good performance in market terms. Ferner et al. (2012) find that a well-performing subsidiary is not typically threatened by closure and can operate more freely in relation to headquarters. This also extends to situations of initiative taking and related issue-selling activities.

\section{The MNC's asymmetrical power distribution}

'Power' can be defined as the ability to constrain others in their choices and, thereby, secure their compliance. Therefore, power is captured in the word 'domination' and is closely related to such notions as subordination, subjugation, control, conformism, acquiescence and docility (Lukes, 2005). It also refers to coercion, where compliance is secured through the threat of sanctions. An MNC's headquarters has the mandate to impose sanctions. However, subsidiaries often comply when they face a threat of sanctions rather than actual sanctions. Therefore, hierarchical power becomes rather hypothetical, as the significance of power lies in the degree to which the subsidiary believes that sanctions will be exercised (Mechanic, 1962). However, headquarters can also secure compliance through rewards (French and Raven, 1959; Raven, 1993) and it can maintain the hierarchical power structure, which is based on its control of resources. Moreover, the headquarters unit serves as the epicenter of regulation and policies - it controls the contexts, procedures and criteria for initiative approvals or rejections. Astley and Sachdeva (1984: 106) suggest that hierarchical power is a product of a formal decree and that subordinates (subsidiaries) obey not because they are dependent on the headquarters but because headquarters have the right to 'exercise power by the virtue of their position'. Consequently, headquarters can exercise command based on legitimized procedures that both actors view as correct.

Hence, hierarchical power, as we describe it above, reflects a balance between domination and authority. According to Lukes (2005), 'domination' implies that headquarters affects the subsidiary in a manner contrary to the subsidiary's interest. This is a coercive type of power in which compliance is secured by restricting the subsidiary from acting or managing as its own nature and judgement dictate. However, this notion stands in contrast to the definition proposed by Clegg et al. (2006), which refers to Max Weber's original notion of power. Here, power enforced by, for example, violence only leads to short-term compliance. In order to establish an enduring and permanent situation of domination, power has to be equated with authority. The notion of authority expresses that compliance is achieved when, for instance, a subsidiary, accepts headquarters' dominance as legitimate, either because the content of 
commands is reasonable or the process explaining the content is viewed as legitimate (Bachrach and Baratz, 1963). In this logic, an MNC is an example of a structure of dominancy that emphasizes compliance with certain rules. However, this structure of dominancy can be transformed into a structure of authority if rules are accepted as a legally rational basis for constraining actions (Clegg et al., 2006).

Some more recent literature on headquarters-subsidiary relationships stresses that an MNC's headquarters is powerful because it controls the allocation of resources to other subordinated units. On the individual level, the headquarters unit controls the career opportunities available to the personnel in subordinated units (in our case, subsidiary managers) (Ferner et al., 2012). Consequently, poorly performing subsidiaries are vulnerable to pressures from headquarters to conform (Tempel et al., 2006). In addition, headquarters can dictate policies that are unfavorable for certain subsidiaries. For example, subsidiary knowledge can be destroyed in the name of standardization, and locally developed practices, such as practices for adapting production to the local market, can be devalued within the MNC (Mir and Sharpe, 2009). In cases where subsidiaries oppose such headquarters views, headquarters can decide to dispose of the 'troublemaking' subsidiaries and exit the situation (Clark and Geppert, 2011).

Clearly, there are situations in which headquarters should actively engage in the management of subsidiaries and situations in which such involvement is a hindrance to value creation at the subsidiary level. According to Mudambi (2011), this depends on the extent of asymmetric information between headquarters and subsidiary - the former possesses an overview of global operations, while the later has specialized (and often tacit) knowledge of local contingencies. Headquarters possesses hierarchical power (which Mudambi refers to as an ownership right), but the central question is whether the headquarters should delegate the 'right to control ownership' to subsidiaries. On the one hand, if headquarters possesses enough information to make decisions leading to value creation at both the headquarters and subsidiary levels, resistance from subsidiaries will lead to rent-seeking behavior (Mudambi and Navarra, 2004). One the other hand, the Weberian type of authority-based power might lead subsidiaries to acquiesce to headquarters' demands even though they recognize that mistakes are being made (Mudambi, 2011).

In conclusion, Diefenbach and Sillince (2011) find that hierarchical power seems to be persistent, and that most social systems are based on stable hierarchical relationships of superiors and subordinates. In fact, even modern network-type organizations (such as those described by Andersson et al., 2007) are highly hierarchical with increasingly comprehensive top-down power and control mechanisms. Therefore, the notion of hierarchy is central in descriptions of how power manifests in headquarters-subsidiary relationships. This is also true in situations of subsidiary initiative taking.

\section{Power, issue selling and subsidiary initiative taking: A skeletal conceptual framework}

Our discussion suggests that both headquarters and subsidiaries can draw on specific forms of power in cases of subsidiary initiative taking (Mudambi et al., 2014). The first form of power resides only at the headquarters level. An MNC is, by definition, a hierarchy, as its headquarters unit formally owns the subsidiaries. Ownership rights held by the headquarters extend to such activities as establishing or closing subsidiaries, hiring and firing subsidiary managers (Hardy, 1996), and approving or rejecting subsidiary initiatives. In this paper, we 
call this type of power hierarchical power. The second type of power relates to certain characteristics of the subsidiary - resources, network position, value-chain mandates, and institutional and market conditions. In this paper, we call this type of power subsidiary power. In addition, we propose that the subsidiary can draw on a third form of power that is derived from its issue-selling activities. These activities aim to influence headquarters' decisions to approve or reject an initiative. In this paper, we call this form of power subsidiary issueselling power. Sources of subsidiary issue-selling power lie in the ability of the subsidiary to attract headquarters' attention to an initiative and in its ability to successfully play power games with headquarters by engaging in lobbying activities (Bouquet and Birkinshaw, 2008; Dutton and Ashford, 1993).

After a discussion of our methodology, we use this skeletal framework in our empirical investigation to explore two questions:

1) What activities do subsidiaries undertake in order to sell their initiatives to headquarters?

2) How do the three forms of power interact in subsidiary initiative taking in relation to headquarters' approval or rejection of an initiative?

\section{Data and methodology}

Our literature review reveals that issue selling in subsidiary initiatives and its link to power are under-researched, novel and worthy of attention, elements that are viewed as the basic rationale for applying an explorative case-study approach (Birkinshaw et al., 2011). In order to better elucidate the subject, we first engage in an empirical investigation. We then use inductive theory building (Welch et al., 2011) to further develop our skeletal framework and to outline avenues for future research.

\section{Sample selection}

We adopted a multiple case-study approach (Eisenhardt, 1989) in which we studied six subsidiaries of German MNCs in France, all of which were active in the manufacturing sector. The selection of France as the host country was based on our need to find rich evidence of subsidiary initiative taking and associated issue-selling activities. Zahra et al. (2000) suggest that subsidiary initiative taking is supported by the presence of complex and dynamic competitive environments, such as that found in France at the time of our fieldwork (Porter et al., 2004). The decision to investigate German subsidiaries in France was the result of the assumption that initiatives in countries that operate on similar economic and technical levels might be more likely to spur intra-firm competition in which processes of issue selling and political maneuvering surface (Becker-Ritterspach and Dörrenbächer, 2011).

In terms of the type of initiatives taken, four subsidiaries (cases A-D; see Table 1) were engaged in domain-developing initiatives - initiatives that went substantially beyond the subsidiaries' mandates because they focused on new markets, new products or new technologies (Delany, 2000). The other two cases (cases E and F; see Table 1) were included because they provided some general insights with regard to issue selling. However, they were excluded from the comparative analysis in order to keep the unit of observation (the focal initiative) stable (Fletcher and Plakoyiannaki, 2011). Detailed information on the sample is provided in Table 1. 
Table 1 about here

$* * * * * * * * * * * * * *$

\section{Data collection}

In each case, one or two in-depth interviews, each lasting about two hours, were undertaken in the subsidiary. Each interview involved the respective subsidiary's CEO. In all cases, data were gathered on the interviewees, the overall organizational setting, the initiative-taking processes and actors' behaviors. In order to gather information on the overall organizational setting, questions were included that took stock of the position and role of the subsidiary in the MNC (e.g. resources, network position, position in the value chain and mandates). Other questions aimed at gathering data on the overall properties of the initiative-taking process in the MNC (e.g. the headquarters' general attitude towards initiative taking, the level of intrafirm competition, procedural rules, actors typically involved and conflict regulation). Finally, we posed questions on specific initiative-taking processes and corresponding actors' behaviors in order to qualify the initiative (e.g. content, and importance and role of the initiative in the subsidiary's strategy) and to gather data on the issue-selling process (e.g. measures undertaken to attract headquarters' attention, lobbying activities and sequencing of issue-selling activities).

The power position of the subsidiary relative to its headquarters was derived from responses to questions focused on the overall organizational setting. Given the diversity in industries throughout the sample, the subsidiary's share of sales in relation to the MNC's total sales was used as a proxy for the subsidiary's power position relative to its headquarters (Ambos et al., 2010; Gammelgaard, 2009). Two factors motivated this choice. First, this measurement operates in market terms, as suggested by Ferner et al. (2012). Second, it acts as proxy for the four types of subsidiary powers that Ferner et al. (2012) suggest lead to good performance. This measurement was further checked using direct questions on the overall position and role of the subsidiary in the MNC (Andersson et al., 2002). More specifically, we categorize the subsidiary's power position relative to headquarters as strong when the subsidiary contributes at least $10 \%$ of the MNC's total sales. We also view this proportion as indicative of a less asymmetrical power relationship.

\section{Data analysis}

Answers to questions aimed at qualifying the context of initiative taking were checked for plausibility during the interviews, while information regarding the subsidiary's initiativetaking activities was internally validated by approaching the topic from different angles using a variety of back-up questions. Where possible, interview data was subject to data triangulation (Denzin, 1978) with data from other interviews and with secondary data that was collected and processed into extensive company profiles. These company profiles drew on a wide array of information sources, including annual reports, business directories, company press communiques, press reports and academic case studies. They aimed at capturing the headquarters' perspective, which was only partially represented in our primary data. MarshanPiekkari et al. (2004: 254) propose that 'unit triangulation' more systematically reflects the multilocational character of the MNC. We went in that direction by explicitly asking the subsidiary CEOs for their perception of the headquarters' perspective. We assume that the validity of these findings was particularly high, as much of the information came from subsidiary managers who had previously held appointments with their MNCs' headquarters. 
All interviews were carried out in German and were subsequently transcribed. Following a rough summarization of the interview transcripts through fact rejection (i.e. the omission of text elements that are irrelevant to the subject of the study; Hossak, 1982), the remaining textual data was coded on the basis of categories derived from extant theory (e.g. issue selling was coded as attention attraction and lobbying). This was followed by a within-case analysis of the individual cases in order to become familiar with each case. The final step consisted of a case comparison aimed at detecting patterns across cases. After comparing the cases according to coding categories, we applied an analytical approach proposed by Eisenhardt (1989: 540f) in which selected pairs of cases were compared in order to detect subtle similarities and differences (see the section 'The relationship between power and issue selling' below).

\section{Empirical findings}

In this section, we first describe the kinds of tactics that the subsidiaries of German MNCs in France used to sell their initiatives to their headquarters. We then explore the interplay among subsidiary power, issue selling power and headquarters' hierarchical power, and the impact of that interplay on headquarters' decisions about the initiatives.

\section{Issue-selling tactics}

Overall, the subsidiaries in our sample undertook a wide variety of issue-selling activities. Typically, subsidiaries attempting to sell initiatives to headquarters simultaneously engaged in attention-attraction and lobbying tactics. We found evidence of all of the aspects of attention attraction and lobbying outlined above.

\section{Attracting headquarters' attention}

Many respondents indicated that good performance was vital for gaining headquarters' attention and support for initiatives. This was, for instance, expressed by the CEO of subsidiary A, who had received headquarters' approval for a domain-developing initiative:

Headquarters put a lot of trust in me and let me develop the initiative. However, this was only because the numbers were 'right'. Of course, you have to provide proper answers when questions arise.

In order to attract headquarters' attention to an initiative, the same subsidiary not only needed to demonstrate good performance in its usual business activities but also excellence in developing new capabilities:

Our new product initiative was only acceptable [to headquarters] because we could show that we had developed the background needed to produce the new product with a high level of precision and quality.... We had to change our outlook, train our workers, hire more skilled people, improve production processes and introduce a sound quality-management system. (CEO, subsidiary A) 
In another company, the subsidiary CEO believe that the subsidiary's reputation with regard to previous initiatives was important for attracting headquarters' attention to new initiatives:

We enjoy a good reputation at headquarters. If we come up with new ideas or innovations, people in headquarters say: 'Oh, yes. That is from [our subsidiary in] France. They always have good ideas.' (CEO, subsidiary E)

However, information about issue framing was scarce. Only one subsidiary CEO openly admitted to framing an issue in a particular way to ensure that it was understood by headquarters. This CEO had maintained close contact with headquarters after serving in a position in the headquarters unit. He had been motivated to frame the issue by a recent wave of reorganization at the headquarters level, which was associated with a shift in the MNC's overall orientation from a technology-driven company focused on the long term to a relatively short-term oriented company driven by financial factors:

Headquarters has experienced so many changes in leading positions recently. Every one of those new managers is gathering a group of controllers around him or her ... They are not experts, but bureaucrats who need to be addressed in an appropriate way. (CEO, subsidiary D)

The scarcity of issue-framing incidences in our sample does not necessarily mean that this tactic is uncommon. Notably, the interviews indicated that this tactic is sometimes associated with manipulation.

Finally, many of the subsidiaries engaged in attention-attraction tactics oriented towards the long term, such as image control and reputation building. For instance, almost all of the subsidiaries felt a need to pro-actively explain difficulties associated with organized labor in France in order to avoid negative attention from headquarters. For example, one respondent stated:

I belong to the group of people who say [to headquarters] that we need to get an additional 1,000 points on Hay's Job Evaluation Scheme due to our labor-related responsibilities. (CEO, subsidiary B)

Lobbying

Lobbying strategies were identified in all cases. In general, the interviewees viewed lobbying as a very important, if not the single most important, tactic for selling a particular initiative. Many of the interviewees' views on the prerequisites of skillful lobbying were similar. One aspect always mentioned was the necessity of personal relationships, as expressed by one interviewee:

[Skillful lobbying] means taking a seat at the right tables, taking part in the right talks and having better 'feelers' out in the company. (CEO, subsidiary F)

Other aspects frequently mentioned in relation to lobbying were the socially skillful handling of personal relationships and, to a certain degree, persistence, as expressed in the following statement: 
From a theoretical perspective, one would assume that a corporation as large as ours follows a rational, strategic approach [when evaluating a subsidiary initiative], but the opposite is the case. It is a highly political process in which who you know, who trusts you and what reputation you have count. Antichambrer [walking the corridors of power] is exactly what you have to do ... That takes time and continual effort. For me, it is a bit like 'small strokes fell big oaks'. (CEO, subsidiary F)

In some cases, external actors were integrated into the subsidiaries' lobbying activities. In one case, the $\mathrm{CEO}$ of the subsidiary let the headquarters know that the initiative was highly regarded by the subsidiary's main customer (a large MNC) with which headquarters was interested in doing more business. In another example, the subsidiary CEO enlisted the help of the subsidiary's chartered accountant to lobby for an initiative at the headquarters:

When our CEO recently came to Paris, I organized a dinner with our chartered accountant. He is one of my best allies when it comes to my idea of growing our business in France. As discussed with him in advance, he mentioned to our CEO that the subsidiary had a lot of money that would be best invested in taking over some competitors. (CEO, subsidiary $\mathrm{C}$ )

\section{The relationship between power and issue selling}

Based on our findings on issue selling, we can discuss the relationship between power and issue selling.

Subsidiary A was a manufacturer of agricultural equipment. It held a strong power position relative to headquarters due to the overall importance of the French market to the MNC and the subsidiary's role in safeguarding the company's market access:

The French market for agricultural equipment is 'the' market [when speaking of markets] in close proximity to Germany. Our subsidiary gives the company a French flavor, which gives us a foot in the door. (CEO, subsidiary A)

According to the CEO, this strategic role enabled the subsidiary to engage in an initiative to develop (and later produce) a completely new product for the public gardening sector (a self-propelled lawn mower):

We made use of our strong main pillar in agricultural equipment to build up the new product. We were strong enough to run that business independently [of our headquarters], albeit on a smaller scale. (CEO, subsidiary A)

The initiative, which was spurred on by the technical expertise and entrepreneurial spirit of the subsidiary CEO, was promoted through issue-selling activities. Attentionattraction efforts mostly took the form of avoiding negative attention during headquarters' regular control activities. The $\mathrm{CEO}$ also mentioned that he attempted to make suggestions for improvements at MNC-wide technical meetings. However, he downplayed these activities, stating:

I have not devised a certain strategy to make me 'known'. (CEO, subsidiary A) 
A similar low-profile approach was taken with regard to lobbying activities. As the CEO stated:

The initiative was discussed with headquarters but not in detail. (CEO, subsidiary A)

For an extended period of time, the initiative relied solely on the subsidiary's own resources. The headquarters was only approached for funding and approval of the initiative when further development required a substantial investment (i.e. a new painting facility). By that time, the initiative had become a valuable resource that added to the power the subsidiary derived from its positioning in the large French market. Given this powerful position, little lobbying was necessary to convince headquarters to approve the initiative.

Subsidiary B was the fourth-largest subsidiary of a large, highly internationalized German MNC in the chemical industry. The subsidiary contributed about $10 \%$ of the MNC's worldwide sales. Moreover, it held 12 global key accounts with large French customers and had some global R\&D responsibilities. This all amounted to a high level of subsidiary power.

According to the CEO of subsidiary B, the subsidiary had previously introduced numerous initiatives to develop its domain. One example was an initiative to develop a newly acquired activity in France into a regional mandate for the entire European market. That initiative was approved by the headquarters, but the approval was not interpreted as the result of issue-selling tactics. As with subsidiary A, subsidiary B worked hard to avoid negative attention. However, activities to avoid negative attention were not associated with any particular initiative but viewed as an attempt to avoid harming the MNC. Moreover, lobbying was not viewed as an issue-selling activity but rather as an important input for the MNC's well-organized coordination process. This MNC operated a corporate unit called 'regional coordination', which channeled lobbying activities, tried to tame conflicts and negotiated solutions among subsidiaries as well as between subsidiaries and product divisions.

In contrast to subsidiaries $\mathrm{A}$ and $\mathrm{B}$, subsidiary $\mathrm{C}$ held little subsidiary power. In general, the $\mathrm{MNC}$ was in the early stages of internationalization and foreign markets played a rather limited role. This was also true for the French subsidiary. Founded as marketing satellite in the late 1980s, the subsidiary distributed chemicals produced at the headquarters. The scale of its distribution activities was relatively small.

The initiative covered by our study focused on achieving substantial, fast growth for the French subsidiary. The subsidiary CEO, who had only recently joined the subsidiary, recalled:

I was very attracted to the idea of turning that little 'rat shop' into a true countrywide player. I developed a business plan and I said to myself: 'In five to six years, we can triple or quadruple our sales'. (CEO, subsidiary C) 
In addition to organic growth, which had typically been the MNC's prime growth method, the subsidiary's CEO was focused on growth through acquisitions:

I would like to grow externally by taking over one competitor or another. (CEO, subsidiary C)

While headquarters, in exercising its hierarchical power, allowed the subsidiary to grow organically to some extent, the subsidiary was not given a green light to pursue acquisitions despite the subsidiary's heavy engagement in issue-selling tactics. In terms of attention attraction, the subsidiary attempted to avoid negative attention by explaining the particularities of the French labor market, such as the need to have a profit-sharing program similar to those seen in many major firms in France.

Intense lobbying for the external-growth initiative also took place at other subsidiaries and at the MNC's headquarters. In addition, the lobbying efforts involved the French subsidiary's charted accountant, as described above. The French CEO even encouraged another German firm to lobby for a focus on acquisitions:

I have a good friend who works at a German firm with which our MNC is attempting to establish a cooperation agreement. That firm's French subsidiary recently took over a competitor. I have arranged a meeting for the subsidiary manager of that French CEO, his German supervisor [my friend], our head of marketing and me. We will enjoy dinner, and they will tell our head of marketing why they focus on acquisitions, why they bought this particular firm and how they managed the takeover. This is meant to pave the way for my idea. (CEO, subsidiary C)

Despite these efforts, the subsidiary's initiative was rejected by headquarters. In the eyes of the French subsidiary CEO, this was mainly due to headquarters' lack of awareness of the importance of foreign markets:

Take the [MNC's] head of marketing. He holds a PhD in chemistry - a very bright man. Unfortunately, he is not very open-minded about foreign markets. (CEO, subsidiary $\mathrm{C})$

However, the subsidiary CEO also indicated that there was a need to enhance the subsidiary's power in order to gain approval for future initiatives:

Even though we have been successful thus far, we need more success if we want headquarters to fulfill our desires. (CEO, subsidiary $\mathrm{C}$ )

Similar to Subsidiary C, subsidiary D's initiative was rejected. Subsidiary D was the French subsidiary of a large German automotive supplier. The subsidiary was established to serve one particular customer, a well-known German car manufacturer that had built a new factory in France. Subsidiary D was unable to derive substantial subsidiary power from the fact that the factory and the car that it produced were highly innovative, as the car did not sell very well. Furthermore, the subsidiary's activities were rather piecemeal in comparison to the overall activities of the German MNC. In addition, the subsidiary was highly dependent on the MNC's headquarters for R\&D. 
Subsidiary D's initiative was borne out of its experiences with this innovative car project. The initiative consisted of a major process innovation that supported the use of lighter materials in car manufacturing. While the subsidiary developed the process innovation using its own resources, substantial investments were required to ramp it up for wider industrial use. The subsidiary CEO, who had a technical background, believed that these investments offered significant potential:

There are no competitors who are as good as we are. No competitor is able to do what we do. Our subsidiary is full of raw diamonds that only need to be dug out. (CEO, subsidiary D)

Based on his conviction, the subsidiary CEO engaged in a number of issue-selling activities. Attention-attraction activities were focused on avoiding negative attention on industrial conflicts that occurred at the subsidiary. In addition, the subsidiary CEO tried to attract attention by referring to the overall innovative character of the car project in which it was involved. However, this did not resonate with headquarters:

They are not experts but bureaucrats. (CEO, subsidiary D)

In order to help headquarters understand the initiative's potential and to overcome headquarters' arm's-length approach to subsidiary management, the subsidiary worked hard to frame the issue according to headquarters' preferences. In addition, the CEO lobbied headquarters on a number of occasions. He presented the initiative during several monthly senior-manager meetings, and he spoke to a number of senior managers with whom he was familiar owing to his 18-year tenure in the MNC.

In the end, however, the initiative was rejected despite the subsidiary's efforts to sell it to headquarters. The subsidiary's power was not strong enough to overcome headquarters' short-term focus on shareholder value:

They [the headquarters managers] want to see cash in one and half years rather than in three years. (CEO, subsidiary D)

In summary, we find that the power relationship between the subsidiary and the headquarters in the two cases in which the subsidiary initiative received headquarters' approval (cases A and B) was less asymmetrical due to the subsidiaries' comparatively strong power. In these cases, subsidiary power originated from market size, access to key customers, control of R\&D processes and the ability to avoid legitimacy problems.

Interestingly, the use of issue-selling tactics seems to have been less pronounced than in the two cases in which subsidiary power was low and where the initiatives were rejected by headquarters (cases $\mathrm{C}$ and $\mathrm{D}$ ).

\section{Theorizing from the cases}

Our findings suggest that the use of issue-selling tactics is a common occurrence when subsidiaries engage in initiative taking. Our cases also reveal that the two major tactics used in issue selling - attracting headquarters' attention and lobbying at headquarters are interrelated, with the former being a prerequisite of the latter. In other words, in their 
lobbying efforts, subsidiary managers recognize the level of attention they have at headquarters and their subsequent manipulations are based on that level of attention. Finally, our cases reveal that attention attraction is not necessarily related to a specific personal relationship between the subsidiary manager and managers at headquarters, while lobbying relies on such a relationship. The closeness of that relationship affects the lobbying behavior.

Clearly, the findings from our exploratory cases require further empirical corroboration. However, our finding regarding the importance of personal relationships between subsidiary and headquarters managers for different issue-selling tactics provides an opportunity for a more thorough theorization of the link between power and issue selling in subsidiary initiative taking. In the remainder of this section, therefore, we introduce a concept that distinguishes between relationship- and non-relationship-based power. In this regard, we follow Lukes' (2005) distinction between 'power to' and 'power over' situations. We then elaborate as to how this concept applies in a headquarters-subsidiary relationship setting before we utilize it to theorize about the link between subsidiary power and issue selling in subsidiary initiative taking.

\section{Concepts of power}

Analyses of power within organizations often depart from Dahl's (1957) notion of power, which focuses on actor A's ability to get actor B to do something that he or she would otherwise not do. Several nuances have been suggested as supplements to this view of power. In his seminal contribution, Lukes (2005) emphasizes a need to focus on actor A's capacity to affect actor B, as power might never actually be exercised. Consequently, it is the threat of a sanction or the promise of a reward that affects B's behavior (French and Raven, 1959). Furthermore, actor A can control the mindset of actor B by shaping the values and cultures of the organization (Hardy, 1996; Lukes, 2005).

Another classical concept of power is found in Lukes' (2005) and Wartenberg's (1990) division of power into 'power to' (do something) and 'power over' (other persons). This distinction is central for our subsequent theorizing, as 'power to' does not necessarily involve a relationship. It may only involve issues of authority and the resources controlled. This form of power can be actively used to introduce changes (Wartenberg, 1990). It may, therefore, be used in ways that favor or disfavor the interests of, for example, certain subsidiaries (Lukes, 2005).

Wartenberg (1990) defines 'power over' as involving a relationship between two actors in an organization. This relationship is hierarchical, and is given as one person's ability to affect the other without the other being able to reciprocate. In our context, headquarters' management can constrain the choices of a subsidiary manager and, thereby, secure his or her compliance (Lukes, 2005).

Clegg et al. (2006) point to the long tradition in the power literature of viewing 'power to' as a facilitating and 'positive' force because its aim is to make changes through creatively accomplished acts (although these changes may later be recognized as having had negative effects). In organizations, 'power to' typically relates to the allocation of resources for the purpose of attaining collective goals, while 'power over' is a prohibitive type of power that leads to compliance and makes actors to do things they would otherwise not do. Therefore, 
the latter has a negative tone. Hence, 'power over' is based on social interaction and can result in domination, which is typically viewed as a negative, constraining experience.

Prior to discussing in detail how the power to/power over concept might help explain the links among subsidiary power, subsidiary issue-selling power and headquarters hierarchical power, we must clarify how the power to/power over concept applies in a headquarters-subsidiary relationship setting. This is visualized in Figure 1.

$* * * * * * * * * * * * * * *$

Figure 1 about here

$* * * * * * * * * * * * * * *$

The power to/power over concept in a headquarters-subsidiary relationship setting

Unlike the many organization studies that focus on power struggles within the same department, a power analysis of a headquarters-subsidiary relationship in an MNC must focus on different independent actors in a hierarchy (Mir and Sharpe, 2009). In Figure 1, this is exemplified by the vertical links. In the case of MNCs, the most salient organizational subunit - the subsidiary - is a legally independent unit (although it is owned by the MNC) that is often located in another country. This means that institutional features and economic aspects of the host country come into play, as indicated in the box on subsidiary characteristics in Figure 1. While its legal status makes a subsidiary more powerful than a typical department, it remains vulnerable, as a subsidiary can be closed or spun off (Benito, 2005). Moreover, mandates and resources are allocated and reallocated to subsidiaries by headquarters, which puts competitive pressure on subsidiaries (Becker-Ritterspach and Dörrenbächer, 2011).

Overall, therefore, hierarchical power seems to be persistent. Although subsidiaries have some power, it is limited to certain areas and contexts (Lukes, 2005). Headquarters can, for instance, deliberately influence managerial decision-making processes across time and space with a high degree of effect (e.g. headquarters can close a subsidiary). In contrast, subsidiaries can typically only operate in selected areas and in specific contexts. One example along these lines would be a case in which a subsidiary is invited by headquarters to participate in negotiations on HRM issues once per year but not in negotiations on financial issues. Within these limits, the subsidiary can be powerful given its subsidiary power and the power derived from issue selling, as well as highly effective (e.g. secure full acceptance of an initiative). However, in general, subsidiaries must be viewed as low-power actors (Bouquet and Birkinshaw, 2008) if we refer to Lukes (2005) notion of power in terms of dominance. Nevertheless, international business concepts, such as the MNC as a heterarchy (Hedlund, 1996), differentiated networks (Nohria and Ghoshal, 1997), federations (Andersson et al., 2007), and court societies (Morgan and Kristensen, 2009), all emphasize a decentralization of decision-making power and the impact of lateral power relations. Consequently, even in cases of dominant power, subsidiaries can be highly influential, especially within specific and selected areas, such as certain value-chain activities, or with regard to a specific initiative (Gammelgaard et al., 2012). This is reflected in Figure 1 by the fact that we exclusively refer to the headquarters-subsidiary power relationship in relation to a particular subsidiary initiative and not to the relationship in general. 
The considerations made thus far have an impact when applying the power to/power over concept in a headquarters-subsidiary relationship setting. From the perspective of headquarters, its 'power to' is equivalent to its hierarchical power. However, hierarchical power can be constrained by subsidiary power, as headquarters will incur some sort of value destruction if it executes its hierarchical power by, for example, closing down a wellperforming subsidiary (Mudambi, 2011). Nevertheless, headquarters retains its general ability to make such a decision. Therefore, by definition, hierarchal power is highly asymmetrical in favor of headquarters and, in principle, it can never be highly asymmetrical in favor of a subsidiary. This does not preclude the possibility that hierarchical power can be less asymmetrical in favor of headquarters in cases in which subsidiaries possess certain characteristics, such as those seen in to the cases presented in this article and visualized in Figure 1. Within this emerging framework of the high-low asymmetric distribution of power, subsidiaries can utilize their issue-selling strategies.

\section{Relationships among subsidiary power, issue-selling power and initiative taking}

We can conclude that although subsidiary power does not directly affect the headquarters' 'power to', the use of such power may lead to value destruction, which makes the power relationship less asymmetrical. Therefore, a certain level of subsidiary power is likely to decrease the asymmetrical distribution of power in favor of subsidiaries. This is evident in the two empirical cases in which the subsidiaries received headquarters' approval for their initiatives (cases A and B). Both subsidiaries held considerable subsidiary power that influenced headquarters' 'power to' make a decision regarding the initiative.

Issue-selling strategies affect the headquarters' 'power over' and might lead the headquarters to approve initiatives that it would otherwise not accept. The effects of subsidiary power and issue selling when negotiating an initiative with headquarters are sequential in the sense that subsidiary power reflects, in some way, the dependence of headquarters on the subsidiary. Issue selling is then the manipulation of that dependency (Mechanic, 1962). This relationship is represented in Figure 1 by the link between subsidiary characteristics and issue selling. We propose that headquarters has the power to reject the subsidiary initiative, but it decides not to do so because it is influenced by the subsidiary's issue-selling tactics. In this regard, our cases reveal that subsidiaries that possess considerable subsidiary power because they create some sort of headquarters dependency need to engage in little or no issue selling to get approval for their initiatives (cases A and B). In other words, those subsidiaries on which headquarters depends to some extent automatically have headquarters' attention, such that lobbying needs less emphasis to be effectual. At the same time, the two subsidiaries in our sample without subsidiary power (cases $C$ and D) could not gain approval for their initiates even though they engaged in issue-selling activities. This suggests that subsidiary power must have an impact on headquarters' 'power to' if the subsidiary wishes to gain approval for an initiative. Issue selling that is not accompanied by subsidiary power is only a power of second rank. As such, it can be easily ignored by headquarters, which applies hierarchical power.

Our findings indicate that the politicking processes in headquarters-subsidiary relationships are influenced by the distribution of power between the two actors. The framework that we propose for future analyses of subsidiary initiative taking builds on the notion of hierarchical power. Headquarters can decide to utilize its hierarchical 'power to' by playing the sanction/reward game (Birkinshaw and Ridderstråle, 1999; Ferner et al., 2012; MacLean et al., 2014; Mir and Sharpe, 2009; Tempel et al., 2006). However, if headquarters units do not directly use their hierarchical power, subsidiaries can engage in issue-selling strategies to 
manipulate decision-making processes in headquarters. In most cases, these issue-selling tactics will be relationship based. However, in contrast to previous findings on issue-selling strategies, they cannot work on their own. Instead, they are highly influenced by the level of subsidiary power, as shown in Figure 1.

\section{Conclusions and perspectives}

This paper demonstrates that attention attraction and lobbying are complementary tactics in issue selling. Thus, long-term oriented attention-attraction tactics, such as image control and reputation building, are prerequisites for successful lobbying. Furthermore, successful lobbying for initiatives requires the availability and careful handling of personal relationships with personnel located at headquarters and in other MNC units.

Moreover, based on comparative case evidence, the paper posits that a low degree of issue selling is needed to obtain approval of an initiative in less asymmetrical headquartersubsidiary power relationships. In cases in which power relationships are highly asymmetrical, issue selling is a necessity, but it is hardly a sufficient condition for obtaining headquarters' approval. This renders issue selling to a second-rank power in subsidiary initiative taking, as it only works in conjunction with subsidiary power. The fact that subsidiary power is more influential on headquarters' strategizing than issue selling is also confirmed by literature. Sargent and Matthews (2006) investigate Mexican maquiladora plants, which are viewed as possessing little power. In that case, domain-developing initiatives were rejected by headquarters and the plant was closed. Another example is found in Fritz and Karlsson's (2006) study of SKF's European subsidiaries, which historically enjoyed strong subsidiary power based on their market dominance, specialized knowledge and government support in their host countries (the subsidiaries were supplying the local armies). However, when contingent influences from the environment (such as tariff reductions and competition from Japanese companies) eroded subsidiary power, SKF's European subsidiaries could not prevent integration and downsizing, nor could they gain approval for domain-developing initiatives.

Our paper confirms the notion that powerful subsidiaries are influential in MNCs, not in a broad sense but, rather, within a constrained area of certain activities. Our findings also confirm the notion that issue-selling strategies can influence headquarters' strategizing and the execution of strategic decisions, as suggested by Erkama and Vaara (2010). However, the paper moves beyond a focus on subsidiaries' abilities to resist headquarters decisions to investigate subsidiaries' abilities to actually 'set the agenda' and obtain headquarters' approval for certain initiatives. By considering the power relationship between headquarters and the subsidiary, we can better understand when issue selling is most useful. Therefore, we suggest that the concept of power should be integrated into models of issue-selling behavior to a much higher degree. Moreover, the concept of power should be considered not from the individual manager's point of view (Dutton and Ashford, 1993) but from a hierarchical perspective.

Our paper also describes a complex relationship between subsidiary power and issue selling. We find that power asymmetries decrease as subsidiary power increases, with the particular level of power asymmetry in a given headquarters-subsidiary relationship serving as the starting point from which subsidiaries engage in issue selling. We also contribute by dividing power into hierarchical 'power to', which is non-relationship based and affected by subsidiary 
power, and hierarchical 'power over', which is relationship based and affected by subsidiary issue selling.

Our framework of subsidiary power and issue selling omits several elements that we suggest should be included in future conceptualizations. For example, the use of issue-selling tactics and the power position of a subsidiary might be influenced by the geographical and cultural distances between the headquarters and the subsidiary. Therefore, it might be worthwhile to study cases involving wider geographical and/or cultural distances.

Furthermore, both headquarters and subsidiaries can play a variety of roles, which influence their mutual relationship as well as the distribution of mandates and power. First, headquarters can take on the role of controller or entrepreneur. Second, headquarters can take the form of a corporate headquarters, a divisional headquarters, a functional headquarters or a regional headquarters (Ciabuschi, Dellestrand and Holm, 2012). How this variety of forms and associated roles influences value-creation opportunities has been investigated (Andersson and Holm, 2010), but the interactions among power asymmetries, issue selling and the different organizational constructs have yet to be investigated.

Finally, certain central aspects of power theory that are not included in our analysis could enrich future analyses. One such element is highlighted in the seminal work by Bachrach and Baratz (1963), which includes aspects of non-decision making or the limitation of decision making to non-controversial matters. In addition, Foucault's (1980) work on power in relation to knowledge has been omitted from our analysis. The same is true for the game-theoretical approach and the effects of repeated power games (Lukes, 2005), as the strategies and outcomes of earlier initiatives are not considered in this paper (Wartenberg, 1990).

\section{References}

Ambos TC and Birkinshaw J (2010) Headquarters' attention and its effect on subsidiary performance. Management International Review 50(4): 449-469.

Ambos TC, Andersson U and Birkinshaw J (2010) What are the consequences of initiativetaking in multinational subsidiaries? Journal of International Business Studies 41: 120.

Andersson U, Forsgren M and Holm U (2002) The strategic impact of external networks: subsidiary performance and competence development in the multinational corporation. Strategic Management Journal 23: 979-996.

Andersson U, Forsgren M and Holm U (2007) Balancing subsidiary influence in the federative MNC: a business network view. Journal of International Business Studies 38(5): 802-818.

Andersson U and Holm, U (2010) Managing the Contemporary Multinational - the Role of Headquarters. Edward Elgar: Cheltenham, UK.

Astley WG and Sachdeva PS (1984) Structural sources of intraorganizational power. A theoretical synthesis. Academy of Management Review 9(1): 104-113.

Astley WG and Zajac EJ (1991) Intraorganizational power and organizational design: reconciling rational and coalitional models of organization. Organization Science 2(4): 399-411.

Bachrach P and Baratz MS (1963) Decisions and nondecision: an analytical framework. American Political Science Review 57: 641-51. 
Becker-Ritterspach F and Dörrenbächer C (2011) An organizational politics perspective on intra-firm competition in multinational corporations. Management International Review 51(4): 533-559.

Benito GRG (2005) Divestment and international business strategy. Journal of Economic Geography 5: 235-251.

Birkinshaw J and Morrison AJ (1995) Configurations of strategy and structure in subsidiaries of multinational corporations. Journal of International Business Studies 26(4): 729753.

Birkinshaw J and Ridderstråle J (1999) Fighting the corporate immune system: a process study of subsidiary initiatives in multinational corporations. International Business Review 8(2): 149-180.

Birkinshaw J, Bouquet C and Ambos T (2006) Attention HQ. Business Strategy Review: 4-9.

Birkinshaw J, Brannen MY and Tung RL (2011) From a distance and generalizable to up close and grounded: Reclaiming a place for qualitative methods in international business research. Journal of International Business Studies 42: 573-58.

Bishop K, Webber SS and O'Neill R (2011) Preparation and prior experience in issue-selling success. Journal of Managerial Issues 23(3): 323-340.

Bouquet C and Birkinshaw JM (2008) Managing power in the multinational corporation: how low-power actors gain influence. Journal of Management 34(3): 477-508.

Cantwell JA and Mudambi R (2005) MNE competence-creating subsidiary mandates. Strategic Management Journal 26: 1109-1128.

Ciabuschi F, Dellestrand, H and Holm U (2012) The role of headquarters in the contemporary MNC. Journal of International Management, 18: 213-223.

Clark E and Geppert M (2011) Subsidiary integration as identity construction and institution building: a political sensemaking approach. Journal of Management Studies 48(2): 395-416.

Clegg, SR, Courpasson, D and Phillips, N (2006) Power and Organizations. London: SAGE Publications.

Cowan D (1991) The effect of decision-making styles and contextual experience in executives' descriptions of organization problem formulation. Journal of Management Studies 28: 462-484.

Crane A (2000) Corporate greening as amoralization. Organization Studies 21(4): 673-696.

Dahl R (1957) The concept of power. Behavioral Science 2: 201-215.

Delany E (2000) Strategic development of multinational subsidiaries through subsidiary initiative taking. Long Range Planning 33: 220-244.

Denzin NK (1978) The research act: a theoretical introduction to sociological methods. New York: McGraw-Hill.

Diefenbach T and Sillince JAA (2011) Formal and informal hierarchy in different types of organization. Organization Studies 32(11): 1515-1537.

Dörrenbächer C and Gammelgaard J (2006) Subsidiary role development: The effect of micro-political headquarters-subsidiary negotiations on the product, market and valueadded scope of foreign-owned subsidiaries. Journal of International Management 12(3): 266-283.

Dörrenbächer C and Gammelgaard J (2010) Multinational Corporations, Inter-organizational networks and Subsidiary Charter Removals. Journal of World Business 45(2): 206-216

Dörrenbächer C and Gammelgaard J (2011) Subsidiary power in the multinational corporation: on the subtle role of micro-political bargaining power. Critical Perspectives on International Business 7(1): 30-47.

Dutton JE and Ashford S (1993) Selling issues to top management. Academy of Management Review 18(3): 397-428. 
Dutton JE, Ashford SJ, O’Neill RM and Lawrence KA (2001) Moves that matter: issue selling and organizational change. Academy of Management Journal 44(4): 716-736.

Eisenhardt KM (1989) Building theories from case study research. Academy of Management Review 14(4): 532-550.

Erkama N and Vaara E (2010) Struggles over legitimacy in global organizational restructuring: a rhetorical perspective on legitimation strategies and dynamics in a shutdown case. Organization Studies 31(07): 813-839.

Ferner A, Almond P, Clark I, Colling T, Edwards T, Holden L and Muller-Carmen M (2004) The dynamics of central control and subsidiary autonomy in the management of human resources: case-study evidence from US MNCs in the UK. Organization Studies 25(3): 363-391.

Ferner A, Edwards T and Tempel A (2012) Power, institutions and the cross-national transfer of employment practices in multinationals. Human Relations 65(2): 163-187.

Fletcher M and Plakoyiannaki E (2011) Case selection in international business: key issues and common misconceptions. In: Piekkari R, Welch C (eds) Rethinking the case study in international business and management research. Cheltenham, Massachusetts: Edward Elgar, 171-191.

Forsgren M, Holm U and Johanson J (2005) Managing the embedded multinational: $a$ business network view. Cheltenham: Edward Elgar.

Foucault M (1980) Power/knowledge: selected interviews and other writings. New York: Pantheon.

French JRP Jr and Raven B (1959) The bases of social power. In: Cartwright D (ed) Studies in social power. Ann Arbor: University of Michigan Press, 150-167.

Fritz M and Karlsson B (2006) SKF - a global story. Informationsförlaget: Stockholm. $\mathrm{http} / /$ investors.skf.com/skf-a-global-story/

Gammelgaard J (2009) Issue selling and bargaining power in intrafirm competition: the differentiating impact of the subsidiary management composition. Competition \& Change 13(3): 214-228.

Gammelgaard J, McDonald F, Stephan A, Tüselmann H and Dörrenbächer C (2012) Characteristics of low-autonomy foreign subsidiaries: value chains, staffing, and intraorganizational relationships. Journal of International Business and Economy 13(1): $65-95$.

Hardy C (1996) Understanding power: bringing about strategic change. British Journal of Management 7: 3-16.

Hart SL and Sharma S (2004) Engaging fringe stakeholders for competitive imagination. Academy of Management Executive 18(1): 7-18.

Harzing AW and Sorge AM (2003) The relative impact of country-of-origin and universal contingencies on internationalization strategies and corporate control in multinational enterprises: world-wide and European perspectives. Organization Studies 24(2): 187214.

Hedlund G (1986) The hypermodern MNC - a heterarchy? Human Resource Management 25(1): 9-35.

Hossak A (1982) Making a summary. London: Methuen.

Ling Y, Baldridge DC and Floyd SW (2005) Toward a model of issue-selling by subsidiary managers in multinational organizations. Journal of International Business Studies 36(6): 637-654.

Lukes S (2005) Power: a radical view. Houndsmill, Bas: Palgrave Macmillan.

Maclean M, Harvey C and Kling G (2014) Pathways to power: class, hyper-agency and the French corporate elite. Organization Studies 35(6): 825-855.

Marschan-Piekkari R, Welch C, Penttinen H and Tahvanainen (2004) Interviewing in the multinational corporation: challenges of the organisational context. In: Marschan- 
Piekkari R, Welch C (eds) Handbook of qualitative research methods for international business. Cheltenham, Massachusetts: Edward Elgar, 244-263.

Mattes J and Späth S (2013) Upgrading foreign subsidiaries in the case of a German multinational company: bargaining processes and strategic and operative levels. Competition and Change 17(2): 129-55.

Mechanic D (1962) Sources of power of lower participants in complex organizations. Administrative Science Quarterly 7: 349-364.

Mir R and Sharpe DR (2009) The multinational firm as an instrument of exploitation and domination. In: Collinson S, Morgan G (eds) Images of the multinational firm. Chichester: John Wiley \& Sons, 247-266.

Morgan G and Kristensen PH (2009) Multinational firms as societies. In Collinson S, Morgan $\mathrm{G}$ (eds) Images of the multinational firm. Chichester: John Wiley \& Sons 167-191.

Mudambi R (2011) Hierarchy, coordination, and innovation in the multinational enterprise. Global Strategy Journal, 1: 317-323.

Mudambi R and Navarra, P (2004) Is knowledge power? Knowledge flows, subsidiary power and rent-seeking within MNCs. Journal of International Business Studies, 35: 385406.

Mudambi R, Pedersen $\mathrm{T}$ and Andersson $\mathrm{U}$ (2014) How subsidiaries gain power in multinational corporations. Journal of World Business 49(1): 101-113.

Nohria N and Ghoshal S (1997) The differentiated network: organizing multinational corporations for value creation. San Francisco: Jossey-Bass Publishers.

Pfeffer J and Salancik GR (1978) The external controls of organizations - a resource dependence perspective. New York: Harper \& Row Publishers.

Porter ME, Schwab K, Sala-i-Martin X and Lopez-Claros A (2004) The Global Competitiveness Report 2003-2004. New York: Oxford University Press.

Raven B (1993) The bases of power: origins and recent developments. Journal of Social Issues 49(4): 227-251.

Saam NJ (2007) Asymmetry in information versus asymmetry in power: Implicit assumptions of agency theory? The Journal of Socio-Economics 36, 825-840.

Sargent J and Matthews, L (2006) The drivers of evolution/upgrading in Mexico's maquiladoras: How important is subsidiary initiative? Journal of World Business, 41, 233-246.

Schulz M (2003) Pathways of relevance: exploring Inflows of knowledge into subunits of multinational corporations. Organization Science 14(4): 440-459.

Sperber D and Wilson D (1995) Relevance: communication and cognition. Oxford UK, Blackwell.

Tempel A, Edwards T, Ferner A, Muller-Carmen M and Wächter H (2006) Subsidiary responses to institutional duality: collective representation in US multinationals in Britain and Germany. Human Relations 59(11): 1542-1570.

Wartenberg TE (1990) The forms of power: from domination to transformation. Philadelphia: Temple University Press.

Welch C, Piekkari R, Plakoyiannaki E and Paavilainen E (2011) Theorising from case studies: towards a pluralistic future for international business research. Journal of International Business Studies 42(6): 740-762.

Williams K and Geppert M (2011) Bargained globalization: employment relations providing robust "tool kits" for socio-political strategizing in MNCs in Germany. In: Dörrenbächer C, Geppert M (eds) Politics and power in the multinational corporation: the role of institutions, interests and identities. Cambridge: Cambridge University Press, 72-100.

Yang, Q, Mudambi, R and Meyer, KE (2008) Conventional and reverse knowledge flows in multinational corporations. Journal of Management 34(5): 882-902. 
Yukl G and Tracey JB (1992) Consequences of influence tactics used with subordinates, peers, and the boss, Journal of Applied Psychology 77: 525-535.

Zahra S, Dharwadkar R and George G (2000) Entrepreneurship in multinational subsidiaries: the effects of corporate and local environmental contexts. Available at: http://www.ciber.gatech.edu/workingpaper/99_00-27.pdf. 
Table 1: Structured case information

\begin{tabular}{|c|c|c|c|c|c|}
\hline $\begin{array}{l}\text { Subsidiary } \\
\text { name }\end{array}$ & $\begin{array}{l}M N C \\
\text { industry }\end{array}$ & Type of initiative & $\begin{array}{l}\text { Type of HQ- } \\
\text { subsidiary } \\
\text { power } \\
\text { relationship } \\
\text { (based on the } \\
\text { SS/TS ratio*) }\end{array}$ & $\begin{array}{l}\text { Use of } \\
\text { issue- } \\
\text { selling } \\
\text { tactics }\end{array}$ & $\begin{array}{l}H Q \\
\text { reaction } \\
\text { to the } \\
\text { initiative }\end{array}$ \\
\hline
\end{tabular}

\begin{tabular}{|c|c|c|c|c|c|}
\hline $\mathbf{A}$ & $\begin{array}{l}\text { Agri- } \\
\text { cultural } \\
\text { machinery }\end{array}$ & $\begin{array}{l}\text { Domain-development } \\
\text { initiative: } \\
\text { New product, product } \\
\text { diversification }\end{array}$ & $\begin{array}{l}\text { Less } \\
\text { asymmetric } \\
(\mathrm{SS} / \mathrm{TS} 10 \%)\end{array}$ & + & Approval \\
\hline B & Chemicals & $\begin{array}{l}\text { Domain-development } \\
\text { initiative: } \\
\text { New market responsibility for } \\
\text { Europe }\end{array}$ & $\begin{array}{l}\text { Less } \\
\text { asymmetric } \\
(\mathrm{SS} / \mathrm{TS} 10 \%)\end{array}$ & + & Approval \\
\hline $\mathbf{C}$ & Chemicals & $\begin{array}{l}\text { Domain-development } \\
\text { initiative: } \\
\text { Growth in sales through } \\
\text { acquisitions }\end{array}$ & $\begin{array}{l}\text { Highly } \\
\text { asymmetric } \\
(\mathrm{SS} / \mathrm{TS}<3 \%)\end{array}$ & ++ & Rejection \\
\hline D & $\begin{array}{l}\text { Auto- } \\
\text { motive }\end{array}$ & $\begin{array}{l}\text { Domain-development } \\
\text { initiative: } \\
\text { New production technology }\end{array}$ & $\begin{array}{l}\text { Highly } \\
\text { asymmetric } \\
(\mathrm{SS} / \mathrm{TS}<1 \%)\end{array}$ & ++ & Rejection \\
\hline
\end{tabular}

Companies removed from the analysis due to significantly different type of initiative

\begin{tabular}{|l|l|l|l|c|l|}
\hline $\mathbf{E}$ & Machinery & $\begin{array}{l}\text { Domain-defense initiative: } \\
\text { Minor product extension }\end{array}$ & $\begin{array}{l}\text { Highly } \\
\text { asymmetric } \\
(\mathrm{SS} / \mathrm{TS} 5 \%)\end{array}$ & + & Approval \\
\hline $\mathbf{F}$ & $\begin{array}{l}\text { Telecommu } \\
\text { nication } \\
\text { services }\end{array}$ & $\begin{array}{l}\text { New organizational solution } \\
\text { for the global organization }\end{array}$ & $\begin{array}{l}\text { Highly } \\
\text { asymmetric } \\
(\mathrm{SS} / \mathrm{TS}<5 \%)\end{array}$ & ++ & $\begin{array}{l}\text { Approval } \\
\text { (modified) }\end{array}$ \\
\hline
\end{tabular}

* SS/TS = approximate ratio of subsidiary sales to the MNC's total sales.

Source: Authors' own compilation 
Figure 1: Relationship between power and issue selling in subsidiary initiative taking

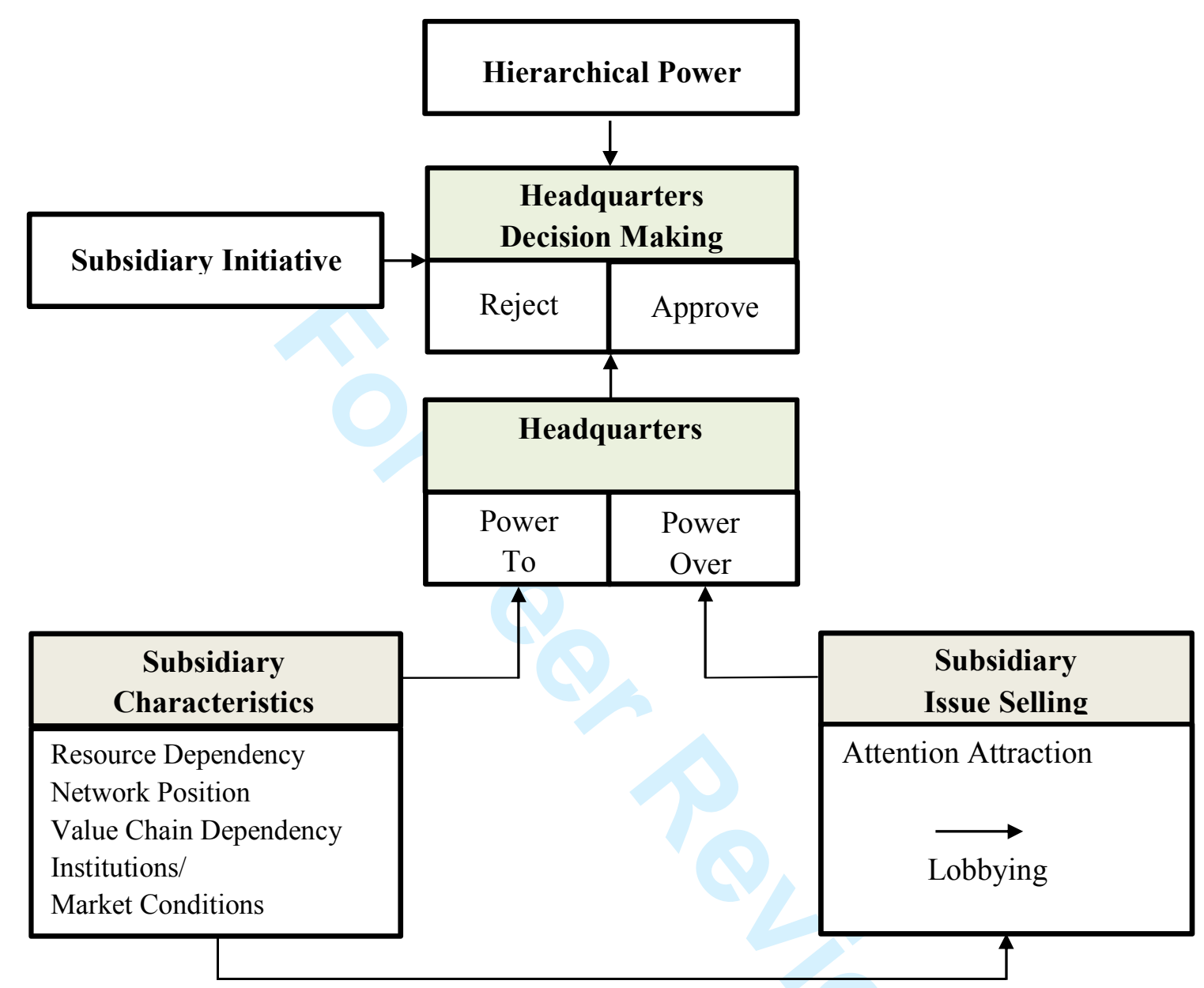


